\author{
Ks. Bogdan CZYŻEWSKI \\ (Gniezno, UAM)
}

\title{
PATER FAMILIAS I JEGO ZADANIA WEDLUG ŚW. JANA CHRYZOSTOMA
}

\begin{abstract}
Aby lepiej zrozumieć nauczanie Chryzostoma na temat ojca rodziny należy najpierw wspomnieć, co rozumiano przez ten termin w przeszłości. W starożytnym Rzymie pater familias był zwierzchnikiem rodzinnym ${ }^{1}$. Ojcem rodziny mógł być wyłącznie męski obywatel rzymski, bez względu na wiek, który nie podlegał władzy ojcowskiej innego pater familias. Wobec innych osób dysponował szeregiem uprawnień, tak daleko idącymi, że nawet posiadał prawo do życia i śmierci powierzonych mu osób. Nad dziećmi sprawował władzę patria potestas, nad żoną manus, nad niewolnikami natomiast dominica potestas.

Biskup Konstantynopola w swoim nauczaniu poświęca wiele miejsca zadaniom, jakie spoczywają na ojcu rodziny. Pater familias jest - według niego - przede wszystkim odpowiedzialny za wychowanie. Ono też stanowi podstawowy obowiązek, jaki składa na jego barki św. Jan Chryzostom². Jako biskup Konstantynopola, wcześniej zaś jako kapłan Antiochii, odczuwał, można by powiedzieć, ewangeliczną potrzebę, by przekazać na temat zadań ojca rodziny nie tyle swoje, co zdanie Kościoła, którego czuł się członkiem i reprezentantem wobec powierzonych sobie wiernych. Jego rozległa działalność literacka
\end{abstract}

\footnotetext{
${ }^{1}$ Por. O. Jurewicz - L. Winniczuk, Starożytni Grecy i Rzymianie w życiu prywatnym i państwowym, Warszawa 1973, 11.

${ }^{2}$ Temat wychowania w nauce Jana Chryzostoma został opracowany, zwłaszcza w kontekście życia rodzinnego: por. J. Czuj, Poglady wychowawcze św. Jana Chryzostoma, „Przegląd Katechetyczny" 31 (1948) 7-11; Z. Domagalski, Wychowanie w rodzinie chrześcijańskiej w pogladach św. Jana Chryzostoma, Lublin 1972 (mps); A. Bober, Rodzina Kościołem domowym wedtug św. Jana Chryzostoma, VoxP 5 (1985) z. 8-9, 193-200; W. Kania, Pierwsza katecheza domowa w ujęciu św. Jana Chryzostoma, VoxP 5 (1985) z. 8-9, 215-222; S. Longosz, Widowiska teatralne zagrożeniem dla życia rodzinnego wedtug św. Jana Chryzostoma, w: Chrześcijanie a życie publiczne w Cesarstwie Rzymskim III-IV wieku, red. J. Śrutwa, Lublin 1988, 135-198; E. Stanula, Rodzina ksztattująca system wartości w ujęciu św. Jana Chryzostoma, w: Wychowanie w rodzinie od starożytności po wiek XX. Materiaty z konferencji (czerwiec 1993 r.), Bydgoszcz 1994, 81-94; T. Kołosowski, Wychowanie religijno-moralne dzieci $w$ rodzinie $w$ świetle traktatu , O wychowaniu dzieci” św. Jana Chryzostoma, „Seminare” 17 (2001) 405-420.
} 
zawiera konkretne wypowiedzi na temat obowiązków ojca rodziny. Najwięcej wskazówek daje w znanym niewielkim piśmie, bo liczącym kilkanaście stron, zatytułowanym $O$ wychowaniu dzieci ${ }^{3}$. Złotousty nie tylko w tym dziele zajmuje się zadaniami ojca rodziny, ale także w innych jego pismach odnaleźć można wypowiedzi, w których poucza każdego pater familias o jego podstawowym obowiazku wobec rodziny.

1. Wychowanie - najważniejszym obowiązkiem dla pater familias. $\mathrm{Z}$ całym przekonaniem należy powiedzieć, że za najważniejsze zadanie ojca rodziny Jan Chryzostom uznaje wychowanie dzieci. Pater familias posiada bowiem władzę nauczania: „Jesteś nauczycielem całej rodziny z mandatu Boga" ". Różnego rodzaju aluzje i porównania pomagają zrozumieć, iż stanowi ono priorytet życia rodzinnego. Zarzuca ojcom, że często w procesie wychowania zwracają uwagę na rzeczy mało istotne, by nie powiedzieć szkodliwe dla dziecka, pomijają natomiast to, co jest podstawą jego kształtowania. Chryzostom piętnuje postawy, w których dba się o wygląd zewnętrzny dzieci, ich ubranie, fryzury, ozdabianie kosztownymi klejnotami. Wszystko to nazywa rozbudzaniem do przywiązywania się do niepotrzebnych rzeczy. „Aby dziecko wychować - powiada Jan Chryzostom - potrzeba dzielnego wychowawcy, a nie złota!" 5 . Nie można wychowywać dziecka w taki sposób, aby życie doczesne stało się dla niego celem samym w sobie, ale pokazać mu przede wszystkim wartości nieprzemijające. Autor rozgoryczony postawą niektórych, a nawet wielu rodziców słusznie stwierdza:

„zepsucia świata nie można dlatego usunąć, bo nikt nie zwraca uwagi na dzieci. Nikt nie mówi do nich o dziewictwie, czystości, pogardzie bogactw i sławy, przykazaniach Bożych, które nam podaje Pismo Święte"6.

Ojciec rodziny powinien zatem skoncentrować się na tym, jak życiową drogę syna skierować ku dobru? ${ }^{7}$ Chodzi zwłaszcza o to, by cały wysiłek poświęcić na kształtowanie duszy dziecka. Jan Chryzostom chwali troskę ojca,

${ }^{3}$ Por. Joannes Chrysostomus, De inani gloria et de educandis liberis, ed. A.M. Malingrey, $\mathrm{SCh}$ 188, Paris 1972, tłum. W. Kania, PSP 13, 157-185, przedruk w: Św. Jan Chryzostom, O malżeństwie, wychowaniu dzieci i ascezie, BOK 19, Kraków 2002, 73-105. W niniejszym opracowaniu korzystam z tego przekładu. Stosuję także numerację tego dzieła, którą zastosował wydawca i thumacz oraz tytuł skrócony: De educandis liberis.

${ }^{4}$ In illud: ,Vidua eligatur” 9, PG 51, 329.

${ }^{5}$ De educandis liberis 16, SCh 188, 98, BOK 19, 79; por. A. Uciecha, Rola ojca w procesie wychowania domowego na podstawie traktatu św. Jana Chryzostoma „O wychowaniu dzieci”, w: Dziecko w rodzinie i społeczeństwie. Starożytność-średniowiecze, red. J. Jundziłł - D. ŻołądźStrzelczyk, t. 1, Bydgoszcz 2002, 205-218.

${ }^{6}$ De educandis liberis 17, SCh 188, 100, BOK 19, 80.

${ }^{7}$ Por. tamże 16, SCh 188, 96-98, BOK 19, 79: „Gdy dziecko się urodzi, cały wysiłek obraca ojciec nie na to, jak jego życiową drogę skierować ku dobru, lecz jak je ładnie ubrać i przyoblec w złote ozdoby. Dlaczego tak czynisz, człowiecze? Może sam o to się starasz, ale po co do tego zła 
bądź też obojga rodziców, by wykształcić dzieci w sztuce, nauce i wymowie. Jednocześnie uważa, że należy z takim samym, by nie powiedzieć jeszcze większym zaangażowaniem, zadbać o formowanie duszy dziecka ${ }^{8}$. Chryzostom zaklina wręcz rodziców i prosi ich, by dobrze wychowywali swoje dzieci. Za należycie spełniony bowiem obowiązek mogą zmazać swoje grzechy i otrzymają nagrodę od samego Boga'. Nasz autor mówi nawet, że właściwe wychowywanie dzieci jest dla ojców wielkim zyskiem, przez co można rozumieć nie tylko wywiązanie się z powierzonego zadania, ale także uznanie w oczach Stwórcy w postaci odpowiedniej zapłaty w przyszłym życiu ${ }^{10}$.

Trudny i mozolny proces wychowania porównuje Jan Chryzostom do pracy malarza i rzeźbiarza, którzy muszą wiele się natrudzić nad swoim dziełem, by zachwyciło innych. Podobnie powinni postępować ojciec i matka, którym przekazuje praktyczne wskazania odnośnie do wychowywania dzieci. Biskup Konstantynopola pisze:

„Jak malarze nad obrazem i rzeźbiarze nad posągiem pracują z wielkim wysiłkiem, tak i wy - ojcze i matko - musicie włożyć wiele starań w wychowanie swych dzieci, tych podziwu godnych obrazów. Malarze ustawiają tablice i dzień za dniem wodzą pędzlem według potrzeby, podobnie gorliwie pracują rzeźbiarze, usuwając to, co zbyteczne, uzupełniając braki. Tak i wy rodzice, jak wykonawcy pięknych posągów, musicie wkładać wszystek trud, aby swe dzieci wychować na piękne obrazy Boga. Usuwajcie to, co niepotrzebne, uzupełniajcie braki; z dnia na dzień baczcie na skłonności swych dzieci, na dobre, by je rozwijać, na złe, by je wykorzeniać"11.

Podobny apel kieruje Chryzostom do ojca rodziny w swoich homiliach, jak na przykład przy komentowaniu Listu św. Pawła do Tymoteusza:

„Weźcie to sobie, ojcowie, do serca! Wychowajcie swe dzieci w karności i posłuszeństwie wobec Pana z całą troskliwością [...]. Strzeżmy zwłaszcza czystości ich serca, gdyż zmysłowa rozkosz czyni w młodości wielkie spu-

przyzwyczajasz dziecko, które jeszcze tego nie rozumie? Po co mu wkładasz klejnoty na szyję? Aby dziecko wychować, potrzeba dzielnego wychowawcy, a nie złota!".

${ }^{8}$ Por. tamże 18, SCh 188, 100-102, BOK 19, 80: „Jeśli dzieci od młodości wzrastać będą bez pouczenia, cóż z nich będzie? Jeśli od wczesnego dzieciństwa do starości wychowani popadają w grzechy, ileż złego uczynią ci, których ucho od młodości przyzwyczaiło się do mów światowych! Ileż starania dokładają wszyscy, aby dzieci wykształcić w sztuce, nauce i wymowie, a nikt nie dba o wyćwiczenie duszy!”.

${ }^{9}$ Por. tamże 19, SCh 188, 102, BOK 19, 80: „Nie przestanę was upominać, prosić, zaklinać, abyście przede wszystkim wychowywali dobrze dzieci. Jeśli kochasz dziecko, okaż to czynem. Otrzymasz za to nagrodę. Posłuchaj, co ci mówi Paweł: «Jeśli dzieci trwać będą w wierze, miłości, świętości i skromności» (1Tm 2, 15). Mając wiele grzechów na sumieniu, przez jedno możesz je zmazać: wychowaj żołnierza dla Chrystusa!”.

${ }^{10}$ Por. De Anna sermo 3, 1, PG 54, 653.

${ }^{11}$ De educandis liberis 22, SCh 188, 106-108, BOK 19, 81. 
stoszenia. Potrzeba tu wiele trudu i uwagi Ożeńmy na czas syna, by swej narzeczonej oddał rękę nieskalaną i czystą. Kto przed małżeństwem był czysty, ten i w małżeństwie dochowa wierności; kto zaś grzeszył przed ślubem, ten to samo będzie czynił po ślubie, bo «nieczystemu każdy chleb jest słodki» (Syr 23, 27). Upominajcie swych synów! Uczmy ich, utrzymujmy ich w bojaźni i groźbie w ten czy inny sposób. Jako cenny dar otrzymaliśmy ich od Boga, strzeżmy ich więc troskliwie i wszystko czyńmy, aby nam ich złośliwy wróg nie odebrał. Niestety, dziś postępujemy przeciwnie. Czynimy wszystko, by w dobrym stanie utrzymać rolę; powierzamy ją wiernemu słudze, szukamy stróża, rządcy, księgowego. Ale żeby nasze dziecko, bezcenne dobro, powierzyć mądremu człowiekowi, który wychowałby je do czystości serca - o tym nie myślimy. A przecież jest ono czymś najdroższym, co mamy. Troszczymy się więc o majątek dla dzieci, ale nie o nie same. Co za głupota! Ćwicz duszę syna, wtedy będzie on miał i majątek! Jeśli jego dusza ulegnie złu, na nic się nie przyda wszelkie bogactwo; jeśli jego dusza jest piękna i czysta, nie przyniesie mu ubóstwo żadnej szkody"12.

Z dotychczas przytoczonych wypowiedzi wynika, że św. Jan Chryzostom wiele uwagi poświęca duszy dziecka, zwłaszcza w dziele O wychowaniu dzieci. Można odnieść wrażenie, że właściwe ukształtowanie jej uznaje za najważniejszy obowiązek należący do ojca rodziny, co nie oznacza, że matka i opiekunowie wolni są od zajęcia się tym jakże delikatnym procesem życia człowieka. Cały jednak ciężar i odpowiedzialność spoczywa na pater familias, co Złotousty uzasadnia w następujący sposób:

„Jesteś nauczycielem i wychowawcą całego twojego domu. Tobie przede wszystkim Bóg polecił stale pouczać żonę i dzieci"13.

W jednym ze swoich dzieł Jan Chryzostom zachęca ojca rodziny, by swoje dzieci powierzył mnichom, którzy są, jego zdaniem, najlepszymi nauczycielami. Nie powinien namawiać je do studiowania podręczników retoryki i pragnąć dla nich pełną sukcesu karierę, ale wszczepiać w nie ewangeliczne ideały $^{14}$. Później jednak Jan zmienił swoje poglądy i stał się bardziej praktykiem niż teoretykiem i odradza posyłanie dzieci do samotni pustelników. Uznał bowiem, że edukacja powinna być oparta na Piśmie Świętym, a dzieci muszą ją otrzymać w domu rodzinnym, obowiązek zaś nauczania spada zwłaszcza na ojca $^{15}$.

${ }^{12}$ In epistolam I ad Timotheum hom. 9, 2, PG 62, 545-547, thum. W. Kania: Św. Jan Złotousty - Poemat wychowawczy, GT 11, Tarnów 1991, 11, przedruk w: Świadkowie naszej Tradycji. Pisma Ojców Kościoła, red. J. Królikowski, Tarnów 2000, 151-153.

${ }^{13}$ In illud: , Vidua eligatur” 9, PG 51, 329.

${ }^{14}$ Por. Adversus oppugnatores vitae monasticae II 3-5, 7, PG 47, 356-360.

15 Por. J.N.D. Kelly, Złote usta. Jan Chryzostom - asceta, kaznodzieja, biskup, thum. K. Krakowczyk, Bydgoszcz 2001, 64. 
2. Sposób kształtowania duszy dziecka. Biskup Konstantynopola ukazuje trudny proces kształtowania duszy dziecka w bardzo plastyczny sposób: ojciec rodziny to król rządzący miastem państwem, którym jest dusza dziecka ${ }^{16}$ :

„Dusza jest państwem. W państwie zaś mieszkają różni ludzie: złodzieje i uczciwi, pracowici i tacy, którzy czynią to, co im wpadnie do głowy. Podobnie i w duszy są przeróżne myśli i uczucia. Jedne walczą z nieprawością - jak żołnierze w mieście; drugie troszczą się o wszystko, co dotyczy ciała i mieszkania - jak urzędnicy w miastach; jeszcze inne wydają zarządzenia - jak zarządcy miasta. Jedne prowadzą nieczyste mowy - jak rozpasani ludzie, inne mówią skromnie - jak czyści. Jedne lubią miękkie życie - jak dzisiejsze kobiety - inne paplają bzdury - jak dzieci. Jedne dają rozkazy niewolnikom - jak zarządcy domu; inne są szlachetne - jak wolni”"17.

Z tego też względu, jak w każdym dobrze zorganizowanym państwie, muszą być ustalone pewne zasady postępowania i prawa obowiązujące obywateli, aby panował w nim ład i porządek ${ }^{18}$. Jan Chryzostom porównuje duszę dziecka z państwem, w innym zaś miejscu mówi o mieście:

„Miastem jest dusza dziecka; miastem nowo założonym, nowo zbudowanym, miastem, które w swe mury przyjmuje za obywateli obcych osadników, z których jeszcze żaden nie przeżył wiele"19.

Na tym jednak biskup nie kończy plastycznych porównań, ale stwierdza, że do tego miasta, czyli do duszy dziecka, prowadzi pięć bram, czyli pięć zmysłów człowieka: mowa, słuch, powonienie, wzrok oraz dotyk. Samo zaś ciało dziecka przyrównuje do muru otaczającego miasto:

„całe ciało niech będzie murem. Bramami miasta są oczy, język, słuch, węch i jeśli chcesz, również dotyk. Przez te bramy wchodzą i wychodzą obywatele, to znaczy przez te bramy wchodzi zguba i błogosławieństwo w życie duszy"20.

Podobnie, jak każde państwo i miasto potrzebuje dobrych praw dla swoich obywateli, tak samo bywa z duszą dziecka. Aby mogła być należycie formowana pater familias musi ustanowić dla niej właściwe zasady, nawet surowe, których nie powinno dziecko w żaden sposób przekraczać. Chryzostom zwra-

${ }^{16}$ Por. De educandis liberis 23; In Epistolam I ad Corinthios hom. 34, 3, PG 61, 290.

${ }^{17}$ De educandis liberis 23, SCh 188, 110-112, BOK 19, 82.

${ }^{18}$ Por. tamże 24, SCh 188, 110-112, BOK 19, 82: „W mieście trzeba praw dla usunięcia złych, a zostawienia dobrych, by źli nie zdobyli wyższości nad dobrymi. Jeśli prawo nie trzyma złodziei w strachu, żadna własność nie jest bezpieczna; jeśli żołnierze obrócą swą wściekłość przeciw obywatelom, zginie wszystko; jeśli każdy przekracza granice i kaleczy prawo drugich, upadnie porządek. Podobnie jest w życiu dziecka”.

${ }^{19}$ Tamże 25, SCh 188, 112, BOK 19, 82.

${ }^{20}$ Tamże 27, SCh 188, 114, BOK 19, 82-83. 
ca uwagę na to, że obarczenie tymi prawami dziecka wyjdzie mu na dobre, co więcej, przyzwyczajone od samego początku do ich przestrzegania, przyjmie je jako całkowicie naturalną rzecz. Biskup z takim naciskiem mówi o tym, aby ukazać ojcu rodziny, że dziecko w sposób szczególny narażone jest na różnego rodzaju niebezpieczeństwa przychodzące ze świata i bardzo chłonne, by je przyjmować. Bez jakichkolwiek zatem praw proces wychowania staje się wręcz niemożliwy i nie przyniesie żadnego rezultatu ${ }^{21}$.

$\mathrm{Za}$ najważniejszy element $\mathrm{w}$ kształtowaniu duszy dziecka Chryzostom uważa mowę, porównywaną do bramy miejskiej. Autor rozwija obraz tej pierwszej bramy prowadzącej do miasta, czyli duszy dziecka wskazując, że winna ona posiadać drzwi i zamek zrobiony ze złota. Uzasadnia to tym, że w duszy nie może mieszkać nikt inny poza Bogiem, dlatego też wykonana jest $\mathrm{z}$ tak drogocennego materiału. $\mathrm{Z}$ tego też powodu przez taką bramę nie powinna przechodzić żadna zła mowa, tylko budująca i godna tak wielkiego mieszkańca, jakim jest Stwórca. Chryzostom podkreśla z naciskiem, że ojciec rodziny winien czuwać nad tym, o czym dziecko rozmawia i chronić je przed zgubnym wpływem otoczenia. Nasz autor zachęca:

„Nauczmy dzieci wypowiadać tylko przystojne i pobożne słowa. Dokonajmy surowego wyboru, aby się nie dostali źli i zepsuci ludzie do dobrych obywateli, tzn. obraźliwe słowa, obelżywe mowy, nieodpowiednie żarty, wyrzućmy z miasta wstrętnych, światowych, rozpasanych osadników. Niech nikt nie przechodzi przez tę bramę, jeno sam Król; niech stoi ona otworem dla Niego i Jego świty"22.

Aby dziecko uchronić przed tego rodzaju wpływami, pater familias winien ustawicznie kontrolować jego mowę ${ }^{23}$. Należy zatem zwracać „,czasem dziecku uwagę, by nikomu nie sprawiało przykrości, nikogo nie obrażało, nigdy nie przysięgało i unikało wszelkiej kłótni”24. Chryzostom radzi ojcu, aby nieodpowiednie wypowiedzi dziecka karać surowym spojrzeniem, zdecydowanym upomnieniem bądź też wpłynięciem na ambicję dziecka. Nie należy natomiast przesadzać z karami, ponieważ odnosi ona wówczas odwrotny skutek. Jan przestrzega, by nie powiedzieć, zakazuje, stosowania bicia za wykroczenia słowne dziecka, gdyż tego rodzaju kary uznaje za złe i niewychowawcze ${ }^{25}$.

\footnotetext{
${ }^{21}$ Por. tamże 25-27.

${ }^{22}$ Tamże 28, SCh 188, 118, BOK 19, 83 .

${ }^{23}$ Por. tamże 29.

${ }^{24}$ Tamże 30, SCh 188, 120, BOK 19, 84.

${ }^{25}$ Por. tamże, SCh 188, 120-122, BOK 19, 84: „Nie karz często biciem i nie przyzwyczajaj się do tego sposobu wychowania. Dziecko ustawicznie bite uczy się gardzić biciem, a gdy to zajdzie za daleko, wszystko będzie daremne. Dziecko winno bać się, ale nie winno być bite; można mu grozić pasem, ale nie należy bić nim; i groźby nie należy w czyn wprowadzać. Nie powinno jednak dziecko wiedzieć, że grozisz tylko słowami, bo wtedy tylko jest groźba zbawienna, gdy dziecko wie, że będzie spełniona. Jeśli mały przestępca zauważy twój podstęp, będzie się śmiał z tego. Niech się boi
} 
Zadaniem ojca rodziny w odniesieniu do mowy jest także wypracowanie u dziecka skromnej postawy i uczenie je miłości. Jan Chryzostom ma na myśli zwłaszcza nieodpowiednie odnoszenie się dziecka do służącego, a także do równych sobie w zajmowanej pozycji społecznej. Dziecko nie może w żaden sposób wyrządzać im jakiejkolwiek przykrości swoim słowem i zachowaniem, tym bardziej zaś oczerniać innych; nasz autor uważa tego rodzaju postępowanie nie tylko za niestosowne, ale za wręcz naganne ${ }^{26}$. Usta dziecka nie powinny wypowiadać ,nic nieprzyzwoitego, obraźliwego, nierozumnego, lecz słowa godne Pana"27. Wytrwała i konsekwentna praca ojca rodziny, a także matki, wychowawców i nawet służących przyniesie pożądane owoce. Powinna być tutaj jednak zachowana wzajemna współpraca wymienionych osób i zgodne stosowanie przez nich tych samych metod wychowawczych ${ }^{28}$. Powodzenie można osiągnąc także poprzez wpajanie zasad dotyczących mowy dziecka od najwcześniejszych lat jego życia. Stosowanie tego rodzaju konsekwentnej postawy sprawi, że dziecko przyzwyczai się do przepuszczania wyłącznie dobrej mowy przez swoje usta, co więcej, ,przyzwyczajenie do dobrego stanie się drugą naturą 29 wychowanka.

Jan Chryzostom wiele miejsca poświęca także drugiej bramie prowadzącej do duszy dziecka, mianowicie słuchowi. Uważa ją za równie ważną i znaczącą co pierwszą, a nawet są one, jego zdaniem, związane i spokrewnione ze sobą, ponieważ słowa wychodzą z człowieka, z czym mamy do czynienia w przypadku mowy, przez uszy natomiast wchodzą przeróżne inne słowa i pozostają w duszy dziecka. Tego rodzaju spokrewnienie autor dostrzega w tym, że „kto nie słucha niczego złego i nieprzyzwoitego, ten też nic złego nie wypowie"30.

Zadanie, jakie spoczywa zatem na ojcu rodziny, to troska o to, by dzieci

bicia, lecz niech nie będzie bity. Bojaźń nie powinna zgasnąć, ale działać w duszy dziecka jak ogień na polu, który wypala wszystkie ciernie u korzenia; niech bojaźń działa jak ostra, głęboko sięgająca motyka, kopiąca rolę. Jeśli twa surowość sprowadziła poprawę, zaprzestaj jej nieco. Natura nasza potrzebuje też łagodności".

${ }^{26}$ Por. tamże 31, SCh 188, 122-124, BOK 19, 84: „Naucz dziecko skromności i miłości dla ludzi. Gdy widzisz, że niegrzecznie odnosi się do towarzyszącego mu w drodze służącego, nie puszczaj tego płazem, lecz ukarz je, choćby pochodziło z wyższego stanu. Wiedząc, że mu nie wolno obrażać służącego, tym więcej będzie strzec, by tego nie czynić względem wolnego i równego sobie. Zamknij mu też usta przed złą mową. Gdy widzisz, że oczernia kogoś, każ mu milczeć i myśleć o własnych błędach".

${ }^{27}$ Tamże 34, SCh 188, 124, BOK 19, 85.

${ }^{28}$ Por. tamże 32, SCh 188, 124, BOK 19, 85: „Naucz dziecko skromności i miłości dla ludzi. Gdy widzisz, że niegrzecznie odnosi się do towarzyszącego mu w drodze służącego, nie puszczaj tego płazem, lecz ukarz je, choćby pochodziło z wyższego stanu. Wiedząc, że mu nie wolno obrażać służącego, tym więcej będzie strzec, by tego nie czynić względem wolnego i równego sobie. Zamknij mu też usta przed złą mową. Gdy widzisz, że oczernia kogoś, każ mu milczeć i myśleć o własnych błędach".

${ }^{29}$ Tamże 33, SCh 188, 124, BOK 19, 85.

${ }^{30}$ Tamże 36, SCh 188, 128, BOK 19, 85. 
niczego niestosownego nie słyszały ani od wychowawców i opiekunów, ani od służących, tym bardziej zaś od rodziców. Chryzostom radzi, aby szukać dla dzieci właściwych opiekunów i nauczycieli, którzy będą pomagać w procesie wychowania. Nie może tego zadania spełniać osoba, która w obecności dzieci prowadzi nieprzyzwoite rozmowy oraz młoda dziewczyna bądź też młoda kobieta, ponieważ tego rodzaju osoby rozpalają u wychowanków ogień namiętności ${ }^{31}$.

Ważne jest też zadbanie o to, co dzieci słuchają. Nie mają to być bajki i mity, ale budujące opowiadania, najlepiej biblijne, które korzystnie wpływają na wyobraźnię i uczą dzieci pozytywnych przykładów ${ }^{32}$. Chryzostom podaje nawet konkretne dwie katechezy do wykorzystania: o Kainie i Ablu oraz o Jakubie i Ezawie. Podsuwa też strategię ich przekazywania, wszystko po to, by przedstawić dziecku historię biblijną w zrozumiały i budujący sposób. Autor wielką wagę przykłada do religijnego wychowania dzieci, zwłaszcza w oparciu o Pismo Swięte. Wręcz w detalach opisuje, jak i kiedy opowiadać wspomniane historie, w jaki sposób je utrwalać w umyśle dziecka poprzez powtarzanie i zadawanie pytań aż do przekonania się, że samo potrafi je opowiedzieć. Chryzostom nie każe jednak poprzestawać wyłącznie na wskazanych historiach biblijnych, ale zachęca, by na odpowiednim etapie rozwoju i zależnie od wieku dziecko poznawało także naukę dotyczącą piekła, potopu, dzieje Izraelitów w Egipcie i wiele innych wydarzeń z biblijnej historii. Zadaniem ojca jest czuwanie nad tym, aby tego rodzaju edukację biblijną otrzymały dzieci, w czym wspierać je ma także matka. $Z$ wypowiedzi Chryzostoma wynika, że mają to robić opiekunowie bądź też wychowawcy, przez co można rozumieć nauczycieli, nad całym jednak tym procesem powinni czuwać oboje rodzice, zwłaszcza zaś ojciec ${ }^{33}$. On bowiem musi odznaczać się nie tylko łagodnością i posiadać autorytet względem swoich dzieci, ale także powinien wytrwale studiować Pismo Święte ${ }^{34}$.

Św. Jan Chryzostom każe ojcu rodziny w całym procesie wychowawczym zwrócić uwagę także na zmysł powonienia, który nazywa trzecią bramą prowadzącą do duszy dziecka. Używając ponownie obrazowego języka wyjaśnia, dlaczego jest on tak istotny w życiu dziecka. Jeżeli ojciec zaniedba przedstawione uwagi, musi się liczyć z przykrymi konsekwencjami w odniesieniu do złego wychowania. Człowiek bowiem, zwłaszcza młody, lubi różnego rodzaju

${ }^{31}$ Por. tamże 37-38 i 53.

${ }^{32}$ Czytanie Pisma Świętego w rodzinie było powszechnie stosowaną katechezą. Więcej na ten temat: por. A. Młotek, Obowiązki wychowawcze rodziców wedtug Ojców Kościoła, „Katecheta” 19 (1975) 107-110; R. Kaczyński, Das Wort Gottes in Liturgie und Alltag der Gemeinden des Johannes Chrysostomus, Freiburg 1974.

${ }^{33}$ Por. De educandis liberis 39-52; zob. W. Kania, Pierwsza katecheza domowa w ujęciu św. Jana Chryzostoma, VoxP 5 (1985) z. 8-9, 215-222.

${ }^{34}$ Por. In epistolam I ad Timotheum hom. 17, 1, PG 62, 591, thum. T. Sinko, w: Św. Jan Złotousty, Homilie na listy pasterskie i na list do Filemona, Kraków 1947, 177-180. 
przyjemne zapachy, chociażby w postaci wonnych ziół, spalanych kadzideł i wonnych maści. Same w sobie nie są one złe, ale powodują niewłaściwe pożądania, a nawet odurzenia, a co za tym idzie brak czujności. Trudno powiedzieć dokładnie, co Jan Chryzostom miał tutaj na myśli. Prawdopodobnie chodziło mu o przesadne stosowanie różnego rodzaju znanych wówczas środków zapachowych, które według niego „budzą zdrożne zachcianki” i stanowią „pokusę do grzechu”. Być może, kiedy mówił o woni kadzideł i ziół, przestrzegał przed wdychaniem ich zapachów, które mogły działać jak narkotyk i uzależniać młodego człowieka. Niektóre bowiem rośliny zawierały niewątpliwie szkodliwe substancje, które były powodem odurzenia i stosowano je w takim właśnie celu. Chryzostom wypowiada się zdecydowanie przeciwko tego rodzaju praktykom, ponieważ człowiek winien „wdychać czyste powietrze, a nie chłeptać, choćby przyjemne, wyziewy". Są one bowiem szkodliwe dla duszy dziecka, stąd też pater familias musi czuwać, by przez niewłaściwe używanie zmysłu powonienia nie wchodziło do niej jakiekolwiek zepsucie, które niewłaściwie na nią działa ${ }^{35}$.

Niezwykle ważnym i jednocześnie niebezpiecznym zmysłem u człowieka, zwłaszcza młodego, jest, zdaniem Chryzostoma, również wzrok, gdyż oczy w sposób całkowicie naturalny i ciekawy patrzą na świat ${ }^{36}$. Złe jego używanie może prowadzić do zgubnych skutków, stąd też pater familias ma za zadanie czuwać nad tym, aby oczy wychowanka kierowały się na właściwe osoby i rzeczy. Biskup dostrzega podwójne niebezpieczeństwo, na jakie narażona jest dusza dziecka, kiedy nie potrafi czuwać nad swoim wzrokiem. W pierwszym rzędzie chodzi o niewłaściwe patrzenie na kobiety. Ojciec rodziny powinien zwracać uwagę na czystość spojrzenia młodego chłopca, by w jego oczach, tym bardziej zaś w duszy, nie budziło się młodzieńcze pożądanie kobiety ${ }^{37}$. Pater familias pomoże mu zachować czyste oczy, kiedy pokazywał mu będzie złe przykłady, jak chociażby o synach Bozych, którzy grzeszyli z córkami ludzkimi, czy o mieszkańcach Sodomy, czy też o karze piekła (Rdz 5, 1-4; $19,1-29)^{38}$. Ojciec powinien także mówić o pozytywnych zdarzeniach, jak na przykład historię o Józefie egipskim, który nie uległ urokowi córki faraona (por. Rdz 39, 7-20) ${ }^{39}$.

Niebezpieczeństwo ze strony wzroku zagraża także, zdaniem Jana, młodemu człowiekowi, kiedy uczęszcza do teatru, przebywa w miejscach publicznych i patrzy na zło, które może wywierać zgubny wpływ na jego duszę. Chryzostom apeluje do ojca rodziny, aby zwracał również uwagę na włosy

\footnotetext{
${ }^{35}$ Por. De educandis liberis 54.

${ }^{36}$ Por. tamże 55.

${ }^{37}$ Por. tamże 60 i 62.

${ }^{38}$ Por. tamże 58.

${ }^{39}$ Por. tamże 61. Jan często wykorzystywał historię Józefa, aby zachęcać swoich męskich słuchaczy do przeciwstawiania się kuszącym kobietom, por. Ad Stagirium II 12, PG 47, 470; In Genesin hom. 62, 4, PG 54, 537; In epistolam ad Colossenses hom. 10, 5, PG 62, 372.
} 
i strój swojego dziecka. Zbyt przesadna bowiem koncentracja dziecka na swoim wyglądzie i niewłaściwa fryzura powodują, że skupia się ono na tym, co zewnętrzne, co więcej, może stać się dla innych powodem grzechu związanego ze wzrokiem ${ }^{40}$. W tych przypadkach Chryzostom daje także praktyczne rady ojcu rodziny:

„Wskaż mu piękne przedmioty, aby jego oczy odwrócić od złych rzeczy, [...] na niebo i gwiazdy, na ziemię i jej kwiaty, na łąki i obrazki w kwiatach, niech tymi rzeczami zachwycają się oczy. Tyle jest piękna, które nie przynosi żadnej szkody!" ${ }^{41}$.

Ostania brama, prowadząca do duszy dziecka, związana jest, zdaniem Chryzostoma, ze zmysłem dotyku. Autor zwraca uwagę ojcu rodziny, aby wychowywał syna na prawdziwego mężczyznę, by nie ubierał go w miękkie i delikatne szaty, nie pozwalał mu sypiać w miękkim łożu i nie narażał go na jakiekolwiek dotyki i poufałości z innymi osobami. Tego rodzaju bowiem postępowanie doprowadzi do właściwego zahartowania się ciała młodego człowieka do tego stopnia, że wychowa się go na prawdziwego żołnierza, który wolny będzie od zniewieściałości i przygotuje go do panowania nad zmysłem dotyku ${ }^{42}$.

3. Ksztaltowanie u dziecka cnót chrześcijańskich. Zadaniem ojca rodziny jest, zdaniem Jana Chryzostoma, nie tylko troska o właściwe uformowanie duszy dziecka, ale także kształtowanie u niego cnót chrześcijańskich, co również można uznać za kontynuację tego samego tematu, w innym jednak wymiarze. Do tej bowiem pory mieliśmy do czynienia ze zmysłami zewnętrznymi, których właściwe wykorzystanie pomaga wypracować u dziecka wrażliwą duszę i bogate życie duchowe. Biskup nasz zajmuje się także wyrobieniem u wychowanka cnót chrześcijańskich, które również kształtują jego duszę. Wymienia ich bardzo wiele, na trzy jednak zwraca szczególną uwagę i poświęca im najwięcej miejsca w swoich dziełach. Chodzi tutaj o męstwo, czystość i mądrość. Każdą z wymienionych cnót charakteryzuje najpierw ogólnie, podając jednocześnie przeciwne im zachowania, w dalszym zaś etapie rozwija swoje myśli, by podać praktyczną naukę ojcu rodziny.

Chryzostom uważa, że siedzibą męstwa są piersi oraz serce, jego cnotami zaś jest pokój i uległość, wadami natomiast - porywczość i upór. Według biskupa Konstantynopola siedzibą pożądliwości są lędźwie, cnotą miłości - czystość, a jej wadą - bezwstyd. Trzecia cnota chrześcijańska - mądrość, nazywana jest przez naszego autora cnotą rozumu, za jej mieszkanie uznaje mózg, za wadę zaś - głupotę. W taki sposób określa on generalnie trzy cnoty

\footnotetext{
${ }^{40}$ Por. De educandis liberis 56-57.

${ }^{41}$ Tamże 59, SCh 188, 156-158, BOK 19, 94.

${ }^{42}$ Por. tamże 63.
} 
chrześcijańskie i zwraca uwagę, by cały wysiłek ojca rodziny był skierowany na rozwijanie i formowanie ich u dzieci, dzięki czemu staną się one wartościowymi ludźmi ${ }^{43}$.

Kiedy nasz Biskup uczy ojca rodziny kształtować cnotę męstwa, używa wielu obrazów i przykładów, aby pokazać, w czym winno się ono przejawiać. Nie jest to bowiem siła fizyczna, na co mogłaby wskazywać sama nazwa, lecz chodzi raczej o wyrobienie u dziecka postaw, które są oznaką prawdziwego męstwa. Uczyć męstwa, to przede wszystkim wdrażać w charakter dziecka różnego rodzaju dobre cechy. Pierwszą z nich jest cierpliwość:

„Należy od pierwszych lat wdrażać chłopca do cierpliwości, gdy go spotka krzywda, a odważnie pójść, wystąpić i spieszyć z pomocą, gdy ujrzy kogo innego pokrzywdzonego" ${ }^{44}$.

Chryzostom nie poprzestaje tylko na wymienieniu i nakazaniu, by tę cechę kształtować u dziecka, ale podaje także ojcu rodziny konkretne wskazania praktyczne, w jaki sposób można ją z powodzeniem wypracować. Chodzi tutaj m.in. o uczenie ich właściwego podejścia do służących: dzieci mają być spokojne, gdy nie znajdują się w centrum zainteresowania i uwagi innych, nie mają się gniewać, gdy nie spełnia się ich zachcianek i życzeń, mają zauważać popełniane przez siebie błędy względem innych. Co więcej, Chryzostom zaleca:

„Niech przy tym ojciec rządzi zawsze jako pan i sędzia, wobec przestępstw niech będzie surowy i stanowczy, przy zachowaniu przykazań łagodny i uprzejmy, niech też nagrodzi syna za zwycięstwo" ${ }^{45}$.

Wzorem dla ojca rodziny w tym względzie winien być sam Bóg, który w taki właśnie sposób wychowuje ludzi i stosuje wobec nich tego rodzaju pedagogię.

Biskup Konstantynopola zaleca także, aby w wychowywaniu do męstwa pobudzać chłopca do gniewu:

„Dobrze jest, gdy chłopca wielu pobudza do gniewu, bo wtedy wyćwiczy się on w opanowaniu swych poruszeń [...]. Niech ojciec lub brat występują przeciw niemu jako napastnicy, by mu dać sposobność do zwycięstwa, albo niech stawi mu kto jako przeciwnik opór, ażeby na nim wypróbować swą siłę. Niech też słudzy dają mu częściej sposobność do gniewu, słusznie czy niesłusznie, aby wśród wszystkich okoliczności nauczył się gniew ujarzmiać. Niewiele to znaczy, gdy mu ojciec sprawi przykrość, bo imię ojca trzyma jego serce w miłości i nie pozwala wystąpić gniewowi. Ale towarzysze wieku, tak

\footnotetext{
${ }^{43}$ Por. tamże 65.

44 Tamże 66, SCh 188, 164, BOK 19, 96.

${ }^{45}$ Tamże 67, SCh 188, 166, BOK 19, 96.
} 
słudzy, jak i wolni, niech mu dają sposobność do niechęci, aby się przyzwyczaił do spokoju i równowagi ducha" ${ }^{\$ 6}$.

Tego rodzaju zachowania służą konkretnemu celowi, wychowują bowiem dziecko do opanowania siebie, zwłaszcza w trudnych sytuacjach, gdy poczucie krzywdy może wzmagać w nich chęć zemsty. Jest to zachowanie przeciwne cnocie męstwa, ponieważ nie należy za krzywdę odpłacać krzywdą. Jako przykład podaje Chryzostom ojcu rodziny postawę św. Pawła, który nie gniewał się, gdy sam doznał krzywdy, ale gniewał się, gdy krzywdzono innych. Podobnie czynił Mojżesz, który na widok krzywdy rodaka wpadł w wielki gniew, choć był człowiekiem najbardziej łagodnym ze wszystkich (por. Lb 12,3); za własną zniewagę nie mścił się, lecz udał się na odosobnienie (Wj $2,13-15)^{47}$. Jan Chryzostom dostrzega w tego rodzaju sposobie wychowania dzieci lekcję dla samego ojca rodziny, który sam się przy tym wychowuje, daje dobry przykład i stara postępować $\mathrm{w}$ dobrym ${ }^{48}$. Na to ważne zadanie nasz autor zwraca często uwagę w swoich dziełach. Analizując m.in. tekst św. Pawła z 1. Listu do Tymoteusza $(4,11)$, stwierdza, że ojciec ma być przykładem mądrości i przestrzegania prawa, winien budzić szacunek i dawać dobry przykład ${ }^{49}$.

Rozwijanie w dziecku cnoty męstwa polega także na wychowywaniu go do samodzielności, która polegać powinna na tym, by nie wymagał od służby czynności, jakie sam potrafi i może spełnić:

„Niech sam się obsłuży i niech pozwala na takie tylko usługi, których sam nie potrafi dokonać; np. wolny nie umie gotować - nie należy się bowiem poświęcać tym pracom, a pracę wolnego zaniedbać. Gdy chłopiec chce wziąć kąpiel, niech nie woła sługi, lecz niech sam się obsłuży; wtedy wolnego będą kochać i pozostaną mu wierni. Niech sobie chłopiec sam przyniesie ubranie z szafy. W kąpieli niech nie woła sługi. Sam sobie wystarczy we wszystkim, co go hartuje i uczyni miłym i uprzejmym dla drugich"so.

Ważnym elementem nauki o cnocie męstwa jest właściwe wyjaśnianie i wprowadzanie u dziecka tego, co Chryzostom nazywa naturą stosunków społecznych, czyli chodzi o status człowieka wolnego i niewolnika. Nasz autor dopatruje się powstania stanu niewolnictwa w fakcie popełnienia grzechu pierworodnego. Wydaje się, że Chryzostom myśli tutaj całkowicie innymi kategoriami, mianowicie bardziej duchowymi niż ludzkimi. Zwracając się do ojca rodziny poleca mu pouczyć na ten temat dziecko w następujący sposób:

„Powiedz mu: «Synu! Na początku nie było niewolników; dopiero grzech wprowadził na świat niewolnictwo. Ponieważ syn (Cham) zelżył ojca, za karę

\footnotetext{
${ }^{46}$ Tamże 68, SCh 188, 166-168, BOK 19, 96.

${ }^{47}$ Por. tamże 69.

${ }^{48}$ Por. tamże 70.

${ }^{49}$ Por. In epistolam I ad Timotheum hom. 13, 1, PG 62, 565, tłum. T. Sinko, s. 131.

${ }^{50}$ De educandis liberis 70, SCh 188, 170, BOK 19, 97.
} 
został niewolnikiem swych braci ( $\mathrm{Rdz} 9,20-25)$. Bacz więc, byś się nie stał niewolnikiem niewolników. Jeśli, jak oni, wpadasz w gniew, postępujesz we wszystkim, jak oni, jeśli nie masz cnoty, jak niewolnik, nie zachowasz też większej godności, jak niewolnik. Staraj się być i pozostać ich panem nie przez swą pozycję, lecz przez cnoty, abyś będąc wolnym, nie stał się niewolnikiem wśród niewolników»»" ${ }^{51}$.

Chodzi zatem o to, by przez swoje niewłaściwe zachowanie, przez grzech popełniany wobec innych, nie stać się w ten sposób niewolnikiem, który krzywdzi drugich i ich poniża.

Cnota męstwa, według Jana Chryzostoma, to także wychowywanie do łagodności, zwłaszcza w odniesieniu do służących. Nie można karać ich za przewinienia, zwłaszcza błahe i mało znaczące, ponieważ każdy, także niewolnik, posiada własną godność i prawa ludzkiej natury. Łagodność i szacunek należy się nie tylko służącym ale także młodszemu rodzeństwu. Jeśli syn zachowa te wszystkie wskazania, przekazane mu przez ojca rodziny, to można zakładać, zdaniem Chryzostoma, że stanie się on człowiekiem, który prawdziwie posiadł cnotę męstwa ${ }^{52}$.

Odpowiedzialność ojca rodziny za dzieci przejawia się także w wychowaniu ich do czystości ${ }^{53}$. Jan Chryzostom ma tu na myśli zwłaszcza chłopców, którzy, jego zdaniem, najbardziej bywają narażeni na wykroczenia przeciw tej cnocie życia chrześcijańskiego. Nasz autor traktuje czystość jako wstrzemięźliwość, czyli postawę polegającą na tym, iż młodzieniec nie daje się uwieść dziewczynie oraz sam jej nie uwodzi ${ }^{54}$. Aby ustrzec go od tego rodzaju niebezpieczeństwa, pater familias powinien starać się o to, by syn, zwłaszcza po piętnastym roku życia, kiedy to żądze gwałtownie go opanowują, nie patrzył na nic nieprzyzwoitego i nie przysłuchiwał się tego rodzaju rozmowom, a zwłaszcza, nie chodził do teatru, gdzie narażony jest na oglądanie różnego rodzaju scen, które później budzą w nim uśpione jeszcze namiętności ${ }^{55}$. Ojciec nie może m.in. dopuszczać do sytuacji, by młodego syna obsługiwała jakaś „młoda dziewczyna, lecz kobieta podeszła w latach i obyczajna”56. Wówczas pater familias uniknie niemoralnego zachowania się swego dziecka i nie narazi go na niezachowanie czystości.

Aby zachować cnotę czystości u swego młodzieńca, ojciec rodziny powi-

${ }^{51}$ Tamże 71, SCh 188, 172, BOK 19, 97-98; podobnie genezę niewolnictwa wyjaśnia Jan w In epistolam ad Ephesios hom. 22, 2, PG 62, 157.

52 Por. tamże 72-75.

${ }^{53}$ Obszerne wypowiedzi na ten temat można znaleźć nie tylko w traktacie $O$ wychowaniu dzieci, ale także w Homiliach na I List do Tymoteusza, por. In epistolam I ad Timotheum hom. 9, 2, PG 62, 546-549, tłum. T. Sinko, s. 151-153.

${ }^{54}$ Por. De educandis liberis 76.

${ }_{55}$ Por. tamże 77-78.

56 Tamże 79, SCh 188, 182, BOK 19, 100. 
nien stosować w tym względzie mądrą pedagogię wobec niego: za jej przekroczenie nie tylko grozić mu karą piekła ${ }^{57}$, ale także wskazywać mu pozytywne przykłady zachowania czystości. Zachęca, aby przygotować chłopcu różnego rodzaju prezenty, które wzbudzą w nim radość, umożliwiać mu rozmowy z ludźmi o wielkiej duchowości, opowiadać mu o niebie, o starożytnych postaciach ze świata chrześcijańskiego i pogańskiego, które odznaczały się czystym życiem ${ }^{58}$. Każe mu również, dla zachowania czystości, często odwiedzać przełożonego kościoła i słuchać od niego pochwał dobrego życia ${ }^{59}$. Wskazuje także na konkretne elementy życia religijnego, które pomagają młodzieży zachować cnotę czystości, a na które powinien zwracać uwagę pater familias. Należy zatem przyzwyczajać synów do praktykowania postu w środy i piątki oraz do uczęszczania do kościoła ${ }^{60}$. Dużą wagę przywiązuje również Chryzostom do modlitwy, do której ojciec rodziny powinien wdrażać swoich synów od najmłodszych lat, ponieważ ona pomoże mu zachować czystośćc1. Winien zatem uczyć dzieci znaku krzyża i modlitwy ${ }^{62}$, śpiewać z nimi pobożne pieśni i psalmy, prowadzić je do kościoła, nawet wtedy, kiedy należy je do tego przymusićc3.

Wszystkie zalecane przez Jan Chryzostoma praktyki pomagają, jego zdaniem, zachować u młodzieńca prawdziwą czystość: „opowiadanie, dozór ojca, jego groźby i obietnice oraz nagroda, jaką Bóg przygotował dla czystych" ${ }^{64}$. Zachowanie cnoty czystości nie oznacza tego, że Jan Chryzostom pragnął odwieść młodzieńców od małżeństwa. Przeciwnie, kiedy wkłada na barki ojca rodziny tego rodzaju zadanie, upatruje w nim przygotowanie do życia małżeńskiego i rodzinnego. W jednym miejscu swojego traktatu $O$ wychowaniu dzieci mówi, co prawda, do niego:

„Nie mówię: Wstrzymaj syna od małżeństwa, poślij go na pustynię i każ mu zostać mnichem. Nie to mówię. Prawda - chciałbym, aby wszyscy żyli jak mnisi. Ale to wygląda za surowo, nie zmuszam więc do tego. Wychowaj żołnierza dla Chrystusa!"65.

Chryzostom nakazuje wręcz ojcu rodziny piętnować wszelkie przejawy rozpusty, chwalić natomiast wstrzemięźliwość; dzięki temu ojciec umocni dobre zasady w sercu syna ${ }^{66}$.

\footnotetext{
${ }^{57}$ Por. tamże 76.

${ }^{58}$ Por. tamże 78-79.

${ }^{59}$ Por. tamże 83.

${ }^{60}$ Por. tamże 78-79.

${ }^{61}$ Por. tamże 80.

${ }^{62}$ Por. tamże 22 i 79.

${ }^{63}$ Por. In epistolam ad Colossenses hom. 3, PG 51, 176.

${ }^{64}$ De educandis liberis 83, SCh 188, 190, BOK 19, 102.

${ }^{65}$ Tamże 19, SCh 188, 102-104, BOK 19, 80-81.

${ }^{66}$ Por. tamże 84, SCh 188, 190, BOK 19, 102: „Mów też swemu synowi o odznaczeniach
} 
Jan Chryzostom poświęca też nieco uwagi wskazaniom ojcu rodziny, w jaki sposób powinien przygotować swoje dziecko do małżeństwa. W Homiliach na Ewangelię wedlug św. Mateusza zachęca go do tego, by znalazł dla syna czystą i mądrą żonę:

„przed nierządem, należałoby takiego (syna) ożenić z roztropną i mądrą kobietą, która odwiedzie męża od najgorszych zajęć i będzie dla niego tym, czym wędzidło dla młodego konia" ${ }^{\circ 7}$.

Podobną argumentację odnaleźć można w traktacie $O$ wychowaniu dzieci. To pater familias ma obowiązek wybrać dla syna przyszłą żonę, zanim jeszcze wstąpi do wojska albo też zajmie się konkretną pracą. Dzięki wcześniejszej trosce o to, by zachował czystość, zawrze małżeństwo jako człowiek niewinny i łatwiej będzie później obojgu zachować nienaruszoną i czystą miłość małżeńską. Gdy zaś „mąż pokocha swą żonę, każda inna kobieta stanie mu się obojętna" ${ }^{68}$. Jest to wyraźna wypowiedź świadcząca o tym, że w narzeczeństwie i w początkowym przynajmniej okresie małżeństwa miłość nie odgrywała większej roli. Dopiero samo życie w małżeństwie miało wzbudzić w nich wzajemne uczucie. $Z$ drugiej zaś strony Chryzostom każe ojcu rodziny chwalić wobec syna różnego rodzaju przymioty przyszłej żony, zwłaszcza jej piękność i czystość oraz przestrzegać go przed rozwiązłym życiem, aby inni patrząc na niego, nie odwiedli jej od małżeństwa z takim człowiekiem, bo jak dodaje Jan: „miłość ma wielkie wymagania” ${ }^{69}$; punktem honoru dla młodzieńca winno być pozyskiwanie względów swojej przyszłej żony ${ }^{70}$. Świadczy to o tym, że jednak miłość i staranie się o przychylność kobiety miała także swoje znaczenie.

Chryzostom każe ojcu czuwać także nad przebiegiem samego wesela swych dzieci, by było wyprawiane zwłaszcza bez teatralnej muzyki i tańców, ponieważ uznaje to za niepoważne zwyczaje. Każe natomiast zaprosić na nie Chrystusa i Jego uczniów ${ }^{71}$.

w służbie wojskowej i w państwowej pracy. Napiętnuj przy tym wszelką rozpustę, a pochwal wstrzemięźliwość. Taka ocena z ust ojca umacnia dobre zasady w sercu młodzieńca. Ubogacona w te nauki jego dusza będzie wydawać święte myśli”".

${ }^{67}$ In Matthaeum hom. 59, 7, PG 58, 583, tłum. J. Krystyniacki, ŹMT 23, 224.

${ }^{68}$ De educandis liberis 81 , SCh 188, 188, BOK 19, 101. Tę sama myśl Jana por. In epistolam I ad Thessalonicenses hom. 5, 3, PG 62, 426.

${ }^{69}$ De educandis liberis 82, SCh 188, 188, BOK 19, 101; ,Jeśli pochwalisz piękność, czystość i inne przymioty wybranej panny i zaznaczysz: «Nie odda ci ona ręki, jeśli będzie wiedzieć, że żyjesz rozwiąźle», uczyni syn wszystko, by swego życiowego szczęścia nie narazić na niebezpieczeństwo. Bo miłość ma wielkie wymagania”.

${ }^{70}$ Por. tamże.

${ }^{71}$ Por. tamże 88, SCh 188, 194, BOK 19, 103: „Wesele syna wyprawiajmy bez gry na flecie czy cytrze i bez tańców. Byłoby wielką głupotą zlekceważenie poważnego oblubieńca tak niepoważnymi zwyczajami. Zaprośmy na wesele Chrystusa - godny jest bowiem tego oblubieniec. Zaprośmy jego uczniów". 
Trzecia cnota chrześcijańska, której wpojenia i wypracowania w życiu dziecka wymaga Chryzostom od ojca rodziny, to mądrość. Uznaje ją nawet za najważniejszą, ponieważ panuje ona nad wszystkim. Mądrość, zdaniem naszego autora, dostarcza bowiem dziecku wiedzy „o Bogu, o dobrach, które są dla nas po tamtej stronie, o piekle i o królestwie niebieskim" "72. Jeżeli dziec$\mathrm{ku}$, a potem młodzieńcowi zaszczepi pater familias tę cnotę, wówczas potrafi ono przez całe życie właściwie oceniać świat, dobra duchowe i ziemskie ${ }^{73}$. Takie bowiem cechy, jak: przywiązanie do bogactwa, władzy, sławy, a zatem do tego wszystkiego, co stanowi przymioty doczesnego życia, nie mają wiele wspólnego z prawdziwą mądrością. Chodzi bowiem o tak zwaną bojaźń Bożą, polegającą na mądrym osądzie wszelkich ludzkich dóbr, które bywają kruche i podlegają zniszczeniu. Nasz autor zapewnia ojca rodziny, że ,jeśliś wychował syna w tych zasadach, wręczysz jego małżonce klejnot, gdy go powiedziesz na gody" 74 .

Jan Chryzostom wychowanie dzieci i młodzieży według wskazanych przez siebie zasad uważa za najlepszą metodę, ponieważ także dalsi ich potomkowie będę kształtowani w taki sposób, dzięki czemu zaistnieje swoisty złoty łańcuch dobrych i świętych rodzin ${ }^{75}$. Z wypowiedzi tego starożytnego Biskupa wynika także, iż sprawą wychowania synów zajmował się przede wszystkim ojciec, córek natomiast matka, której zalecał stosować te same zasady w odniesieniu do córek. Nie oznacza to jednak, że należało niewolniczo trzymać się tego podziału. Nasz autor zachęca bowiem także matki do tego, by brały udział w wychowaniu nie tylko córek, ale także synów i powstrzymywały ich, zwłaszcza od pijaństwa oraz uczyły zachowania czystości ${ }^{76}$.

Rola ojca rodziny w nauczaniu św. Jana Chryzostoma przyrównana jest do roli biskupa $\mathrm{w}$ diecezji: ma on zachęcać i nauczać. Wynika to z całej bogatej rzymskiej tradycji rodzinnej, w której znana jest rola pater familias będącego typem prawdziwego ojca na wzór patriarchalnej zależności: w państwie taką rolę pełni cesarz, w Kościele biskup, w judaizmie rabin, a w rodzinie oj-

${ }^{72}$ Tamże 85, SCh 188, 192, BOK 19, 102.

${ }^{73}$ Por. tamże 86.

${ }^{74}$ Tamże 87, SCh 188, 192-194, BOK 19, 103.

${ }^{75}$ Por. tamże 88.

${ }^{76}$ Por. tamże 90, SCh 188, 196, BOK 19, 103: „Niech i matka w podobny sposób trudzi się w wychowaniu swej córki. Przede wszystkim - niech ją oddala od przepychu świata i wszystkiego, za czym gonią hetery. Niech czyni wszystko według wyżej podanych przepisów. Niech powstrzymuje matka syna i córkę od zbytku i pijaństwa - to jest najważniejszy środek do zachowania czystości. Młodzieńcom sprowadza żądzę pokusy - dziewczęta zaś skłania do zbytków i lekkomyślności. Trzeba to wszystko pokonać. Wtedy będziemy podobać się Bogu, gdy wychowamy bojowników Bożych. W ten sposób będziemy mogli z dziećmi dojść do dóbr, jakie obiecał Bóg tym, którzy Go kochają". 
$\operatorname{ciec}^{77}$. Wydaje się, że Chryzostom przyjmuje grecko-rzymski typ pater familias. $\mathrm{W}$ obu bowiem przypadkach najważniejszym zadaniem rodziców było nie tylko danie życia potomstwu, ale także odpowiednie ich wychowanie, co przejawiało się w tym, że po ukończeniu siedmiu lat, chłopiec przechodził pod szczególną opiekę ojca. On też był właściwym jego wychowawcą ${ }^{78}$. Należy jednak dodać, że często w Grecji nadmierne zajmowanie się synem uchodziło za śmieszną figurę ${ }^{79}$.

Ojciec posiada $\mathrm{w}$ rodzinie niekwestionowany autorytet, on jest przede wszystkim odpowiedzialny za wychowanie, zwłaszcza synów. Dlatego też pozycja kobiety w rodzinie choć jest ważna, to jednak nierówna z mężczyzną, jego bowiem rola jest zawsze decydująca. Należy także podkreślić, że Jan Chryzostom stawia niezmiernie wysokie wymagania zarówno dzieciom, jak i rodzicom. Przedstawiony przez niego model wychowania może stanowić pewną trudność dla ojca rodziny, zwłaszcza wówczas, kiedy jego życie dalekie jest od wzoru i sam nie potrafi dawać dobrego przykładu, co należy do jego obowiązku w trudnej pedagogii rodzinnej.

\section{PATER FAMILIAS ET SON ROLE D'APRÈS JEAN CHRYSOSTOME}

\section{(Résumé)}

Dans le présent article nous souhaiterions présenter le rôle du père à l'appui de l'enseignement de Saint Jean Chrysostome. L'évêque de Constantinople se consentre particulièrement sur le sujet des tâches principales du père au sein de la famille. Pater familias occupe d'après le Saint Jean un rôle principal dans l'éducation.

D'après Jean Chrysostome l'éducation reste entièrement dans les compétences du père. L'évêque souligne en particulier l'importance de l'éducation des enfants. Le père est leur maître et il prend la responsabilité pour l'avenir des enfants. C'est le père même qui doit préparer l'âme de l'enfant pour que ce dernier puisse accuillir le Dieu. D'après le Saint Jean Chrysostome, pater familias est également responsable de former chez l'enfant des certaines vertus chrétiennes de bases, telles que : courage, sagesse et pureté. Le rôle le plus important dans le processus de l'éducation repose sur l'obligation de présenter un bon exemple aux yeux des enfants. Cette obligation reste dans les compétences du père, celle de la mère ainsi que celle de tous ce qui participent dans l'éducation de l'esprit et de coeurs enfantins.

${ }^{77}$ Por. J. Krykowski, Nauka o malżeństwie, rodzinie i wychowaniu [Jana Chryzostoma] (wstęp), BOK 19, Kraków 2002, 31.

${ }^{78}$ Por. J. Kołaczkowski, Rodzina jako środowisko wychowawcze w starożytnej Grecji i Rzymie, SG 12 (1998) 179-187.

${ }^{79}$ Por. H. Marrou, Historia wychowania w starożytności, thum. S. Łoś, Warszawa 1969, 329-330. 
